pebbles cemented with white limestone, and gradwally changing upward into a firm, barren, homogeneous limestone.

This formation was in continuation of, or sometimes below, the horizon of the Exogyra arietina marl. Here, then, was the solution of the problem of the San Marcos. The rocks before me were of the later cretaceous, deposited upon the gravel and shingle which had formed the bed of a river during the period of emergence. They had choked up and rendered impervious the superficial layers of the river-bed, but doubtless left the lower gravel and sand beds in as good condition for carrying water as ever. To make the evidence complete, I found, on examination of the rock $\alpha a$, which lies only a few feet above the river, that it is the soft limestone of the later cretaceous, containing numerous specimens of Gryphaea laeviuscula R., - a fossil found in great abundance a short distance east and north of Austin, and there occurring at the top of the Austin limestone.

We have, then, the channel, and need only to account for the water to fill it. The Blanco River, in a westerly direction from San Marcos, is about fifteen miles distant. In the upper part of its course it is a running stream of considerable volume; but that the whole of the old bed is to some extent permeated by the waters of the underground river.

The extent and direction of this underground channel, and the determination of other streams than the Blanco which may be tapped by it, are promising subjects of future investigation, which I hope at an early date to undertake, not only in the hope of gaining, by a study of the amount of erosion of the older rocks, some idea of the duration of the interval between the two periods of rock formation, but of obtaining some information concerning the fresh-water life of that period. EDwIN J. Pond.

Austin, Tex., May 18.

\section{Electrical phenomena at the Washington monument.}

In various numbers of Science of recent dates have appeared notices of certain electrical phenomena experienced on western mountain-peaks. The peculiar effects experienced consist in general of a hissing or crackling sound accompanying single discharges, or a continuous flow of sparks, and the characteristic tingling sensation when a finger is presented to any metallic object near by. These experiences, despite the common belief, are not rare,

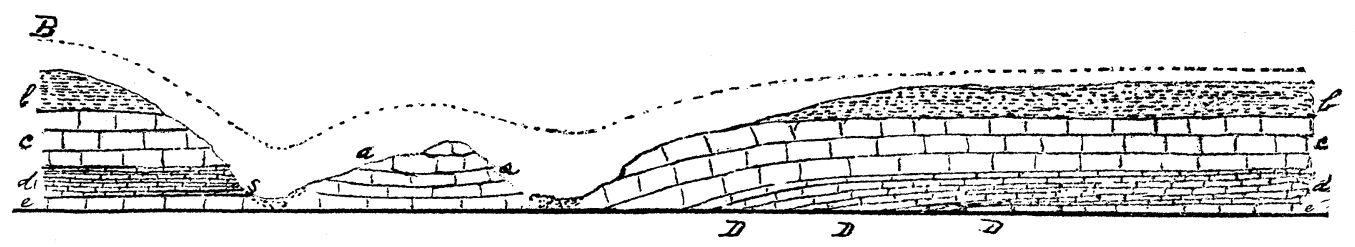

SECTION OF CRETACEOUS ROCKS AT SAN MARCOS, HAYS COUNTY, TEX., LOOKING SOUTH.

$D D D$, principal springs; $B$, hill upon which is the Chautauqua assembly building; $a a$, later cretaceous limestone, with Exogyra laeviuscula R.; $b b$, Exogyra arietina marl; $c c$, firm limestone, with Terebratula Wacoensis R. and Pecten quadricostatus Sowerby; passing into $d d$, thin-bedded soft limestone, with Ostrea carinata Law and numerous fossils of types Ostrea, Gryphaea, Turritella, Pecten, Cardium, Cypricardia, Trigonia, Toxaster, and Ammonites; $e e$, hard but broken limestone, with Caprinas.

below the point west of San Marcos it loses size rapidly, and at the point where the International and great northern railroad crosses it, and below, it is for the greater part of the year only a dry bed with occasional pools of standing water.

It has evidently cut through the overlying deposits, till it has reached the ancient bed of the San Marcos, which, thus filled with water, has been enabled to clear away whatever later deposits lay upon its ancient bed back to the present source of the San Marcos River.

To a geologist the question would at once occur, Why has not the current opened the whole of the old bed, and so caused the abandonment of the present bed of the Blanco long ago? The answer lies in the configuration of the older cretaceous strata at its present source. The old river had cut under what was the overhanging cliff of the hard limestone $c c$, causing it to dip abruptly, as represented in above section, and then found the least resistance in cutting a channel from the softer Ostrea carinata bed rather than in carrying away the fallen mass of the harder limestone. Hence the rocks of the old river-bed proper, at $a a$, though very soft, are protected from further erosion from beneath by the stratum $c c$.

There are, however, small springs at $s$, which show nor confined to certain persons. At Pike's Peak these electrical manifestations are of frequent occurrence, and a list has been published (Report of chief signal officer, 1882, p. 893) showing the accompanying meteorological conditions in fifty-six instances, and proving that these electrical phenomena are closely connected with the occurrence of hail, snow, and thunder-storms. At these times it is easy to obtain sparks from woollen or fur garments, and to receive shocks on opening the door of the stove, or touching any metallic body. Again, at Fort St. Michael's (I bid., 1881, p. 768) during the coldest weather of winter, and always after a snow fog, " the air is so electrified that the hair upon any loose fur stands up, and a spark can be drawn by presenting a finger to the tip of a single hair."

In all these cases the observer may be considered as an insulated (perhaps, as in the case of one of your correspondents, he may stand upon a thick woollen Navajo blanket) body, which, because of the electrification of the air, acquires a charge. Contact with a body, in better, although perhaps not very good, connection with the ground, results in a discharge, with the described effects, varying in intensity with the degree of electrification. This condition of things is in part, I think, imitated in some experiments I have made at the top of the Washington 
monument, during thunder-storms. The apparatus used consists of a large insulated collector, a modified Mascart electrometer, and Mascart insulators and the necessary adjuncts. As the thunder-clouds approach, the electrometer-needle becomes very active, and, after considerable oscillation, begins to move steadily in one direction (generally negative), until a deflection indicating, for example, a potential of three thousand volts, is reached, when, simultaneous with a flash of lightning, occurs a quick drop to zero, to begin again slowly to increase, and then more rapidly, until the next flash of lightning. So perfect is this correspondence, that the lightning can be timed as accurately from the indications of the electrometer as by direct vision. If at this time a finger be held out towards the collector, sparks are given, with the accompanying crackling and hissing, and the tingling sensation in the finger. In such a case, the observer is simply grounding the insulated charged collector. The greatest sparking distance, in our experience thus far, as determined by direct measurement, was a little under four millimetres. I have never found any difference (as one of your correspondents intimates) in the sparking distance, depending on the finger. The potential of the air, however, as shown by the electrometer readings, is constantly fluctuating, often very rapidly, and at certain times the potential of the air is zero. Of course, a finger presented at such a time, fails to draw a spark.

To imitate more closely the conditions of the mountain-side, the previous arrangement was reversed, and the observer insulated by standing on a Navajo blanket folded several times. This is but poor insulation, though it answered the purpose. Standing close to the open window of the monument, the results were as anticipated. My hair stood on end, and, on presenting a knuckle to the iron framework, a spark passed. I should remark that these effects were only experienced during a thunderstorm. I tried the experiment at other times, without success.

There are two further points of interest to which attention is called. Professor LeConte has instanced (Science, ix. No. 205) the case of the survey party on one of the San Juan mountains, where " a sudden cessation of the distressing electrical effects was experienced whenever there occurred a flash of lightning." This is confirmed by what precedes; and our electrometer readings make it certain that every lightning-flash relieves the electrical tension, and gives us also the means of estimating the electromotive force producing the disruptive discharge, and the electric strength of the air, under natural conditions. The second point of interest is the effect of electrification upon the water-particles present. Lord Rayleigh has shown how the character and direction of a fine stream of water may be altered by electrical influences; for example, a stick of sealing-wax, when rubbed, distorting a fine jet of water. Effects of the same character I noticed in the jet of water issuing from the nozzle of the collector. 'When the collector' was ' grounded,' the stream would preserve a certain even, rounded character, breaking into drops some four inches away from the place of issue. Removing the ground connection, the stream would twist and split into sprays with the increasing electrification. Simultaneous with a fiash of lightning, this distortion ceased, and for the moment the stream resumed its first character, only to be again distorted, and repeat the same operation with the next lightning-flash.

Cambridge, May 25. Alexander McAdie.

\section{Railway jubilee, Paris, I887.}

I am requested by the executive committee in Paris to ask the favor of appealing through your columus for the loan of any objects, books, medals, drawings, etc., relating to the history of railways, and means of transportation generally, both ancient and modern, in this country.

I am directed, also, to say that all expenses of forwarding and returning the same to the lenders, packing and unpacking, will be defrayed by the executive, that each object will be insured for the value the lender may put upon it, and that special attendants will be told off for their safe custody.

All communications on the subject may be addressed to M. G. Senechal, 8 Faubourg Montmartre, Paris, or to Mr. George L. Fowler, M.E. (of New York City), commissioner in charge for the United States, Palais de l'Exposition, Bois de Vincennes, Paris, France. By addressing communications direct to Paris, much valuable time will be saved.

Chicago, Ill., May 23. JOHN W. WESTON.

\section{The maxillo-palatines of Tachycineta.}

With respect to what your correspondent says in regard to a drawing of mine, I can only say that the skull of $T$. thalassina from which it was made is a perfect one, and my copy correct in all particulars. This is more than I can say for the reproduction of it (Science, No. 223, fig. 1); but however this may be, it at least affords me now the opportunity to yield gracefully to my critic, for I am free to confess that the maxillo-palatines of that skull are 'imperfect' and 'broken off' - on paper - by Mr. F. A. Lucas; as any one may see who cares to compare my drawing in the Proceedings of the Zoölogical society of London (Dec. 1, 1885, p. 899, fig. $F$ ) with his copy of it in Science, to which I refer above.

Fort Wingate, N.Mex., May 20.

R. W. Shufedit.

\section{No parietal foramen in Tritylodon.}

Dr. George Baur of the Peabody museum, New Haven, has been recently studying the fossil vertebrates in the British museum of natural history. At my request he has kindly made a careful study of the skull of Tritylodon, and finds that Professor Owen's observation of a foramen between the parietal bones is incorrect. He writes (London, May 8), "Ich habe Tritylodon hier genau untersucht, ein Parietal-Foramen existirt nicht; es ist wenigstens keine Spur desselben nachweisbar." This contradicts, without question, the suggestion I made in a recent number of Science, upon the strength of Professor Owen's observation, that there was probably a pineal eye of considerable size in Tritylodon. I hasten to make the correction, before the suggestion goes any further. Although it has proved incorrect, I think any one who will examine Professor Owen's figure and description of the Tritylodon skull (Quart. journ. geol. soc., 1884) will admit that there was sufficient ground for this conjecture.

Princeton, N.J., May 26. 